DEPARTMENT OF THE INTERIOR

U.S. GEOLOGICAL SURVEY

\title{
DELINEATION OF FLOOD HAZARDS IN THE RUELAS CANYON QUADRANGLE, PIMA COUNTY, ARIZONA
}

By Robert M. Myrick and B. N. Aldridge

Prepared in cooperation with the ARIZONA DEPARTMENT OF REVENUE 